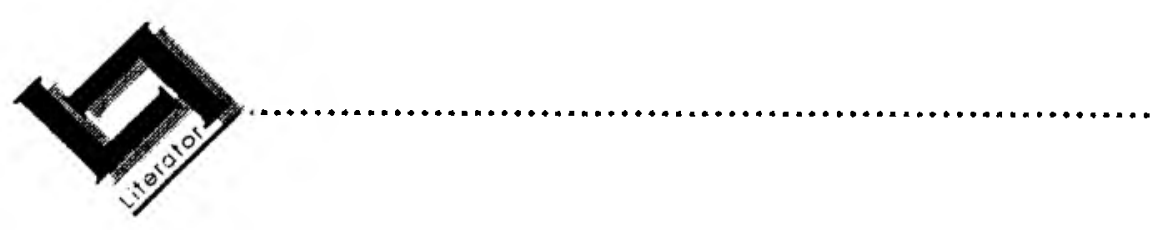

\title{
Dagboeke as oorlogsdokumentasie: Johanna van Warmelo se dagboek en haar belewing van die Anglo-Boereoorlog
}

\author{
Rita van der Merwe en Jackie Grobler \\ Departement Geskiedenis en Kultuurgeskiedenis \\ Universiteit van Pretoria \\ PRETORIA \\ E-pos: jgrobler@postino.up.ac.za
}

\begin{abstract}
Diaries as historical documentation: Johanna van Warmelo's diary and her experience of the Anglo-Boer War

Johanna van Warmelo resided in Sunnyside, Pretoria, with her mother virtually throughout the Anglo-Boer War. She was 23 years old when the war broke out. Her fiancé, whom she later married, lived in Holland. Johanna started a diary immediately after the outbreak of the war. In this she not only wrote down factual reports, but also her perceptions of the war and the belligerents. The diary grew into seven volumes of more than a thousand pages.

After serving as a nurse in the Irene Concentration Camp. Johanna in 1901 became involved in the spying activities of the Secret Service Commission of the Boers in Pretoria. Through assisting the famous scout J.J. Naudé, she and her mother formed a crucial link between the Boer commanders in the field and President Kruger in Europe. She later related those experiences in The Petticoat Commando. It was published in both English and Dutch and eventually also in Afrikaans and became one of the classic factual tales of adventure of the AngloBoer War. In this article her diary is analysed as a source on the war.
\end{abstract}

\section{Inleiding}

Dit was veral tydens die Victoriaanse era wat met die Anglo-Boereoorlog ten einde geloop het, mode vir jong meisies om dagboeke aan te hou. Meestal het dit slegs uit hartstogtelike ontboesemings bestaan wat op die oog af nie van veel akademiese waarde was nie. By verdere ondersoek blyk dit dikwels dat die 
dagboeke 'n blywende nalatenskap vir die studie van sosiale of samelewingsgeskiedenis kan uitmaak. Johanna van Warmelo se oorlogsdagboek hoort tot hierdie kategorie.

\section{Wie was Johanna van Warmelo?}

Johanna van Warmelo sal benewens die inhoud van haar dagboek ook onthou word as die skryfster van Die Kappie Kommando. Sy is in 1876 as predikantsdogter in Heidelberg, Transvaal, gebore ${ }^{1}$ Haar pa, ds. N.J. van Warmelo, is oorlede toe sy slegs 16 jaar oud was. Na sy afsterwe het Johanna en haar moeder, Maria, 'n Voortrekker-nasaat en vurige patriot, hulle op die landgoed Harmony in Pretoria gevestig. Haar drie broers Dietlof, Willem en Fritz het voor die uitbreek van die Anglo-Boereoorlog in Nederland studeer, waar sy hulle besoek het en sodoende haar toekomstige man, ds. Louis Emst Brandt, toe nog student, ontmoet het. Haar ouer suster, Line, was met advokaat Henry Cloete getroud en het in die Kaapkolonie gewoon.

Ten spyte van die feit dat Johanna in Transvaal woonagtig was, waar die geleentheid vir 'n dogter om formele skoolopleiding te ontvang, maar skraal was, het sy die beste opvoeding vir dié tyd ontvang - aan die Kaapse Good Hope Seminary. Sy het die tradisionele dinge wat van 'n jong meisie van dié tyd verwag is, soos om naaldwerk-, klavier-, sang- en skilderlesse te neem, bemeester. Vir al dié vaardighede het sy talent geopenbaar, maar was veral baie lief vir musiek. Op jeugdige ouderdom het sy ook 'n belangstelling in lees en skryf openbaar. Sy het 'n wye leeskennis as jong vrou gehad (Engels, Frans, Duits en Nederlands). Die belangstelling het nooit afgeneem nie. Haar skryfwerk het begin deur korrespondensie aan 'n baie groot groep mense In later jare het sy na ernstige skryfwerk oorgeskakel.

\section{Die kultuurhistoriese waarde van Johanna van Warmelo se oorlogsdagboek}

Die totale omvang van die oorlogsdagboek is meer as ' $n$ duisend bladsye. Die sewe volumes vorm tesame 'n waardevolle bydrae tot die studie van die samelewingsgeskiedenis van Pretoria gedurende die oorlogsjare. In die eerste plek is dit ryk aan historiese feite, want sy het op byna elke bladsy van een of ander oorlogsinsident melding gemaak. Sy het nie daarop aanspraak gemaak dat die berigte korrek was nie, maar het gemeld dat dit op hoorsê berus het In meer as een inskrywing het Johanna oor die uiteinde van die oorlog bespiegel. Tot en met haar vertrek na Europa enkele weke voor vredesluiting, het sy die

1 Die meeste van die inligting in hierdie artikel kom uit die M A.-verhandeling van M E (Rita) van der Merwe, Johanna Brandt en die kritieke jare in Transvaal, 1899-1908 (1989) 


\section{Jobanna in verpleegstersuniform}

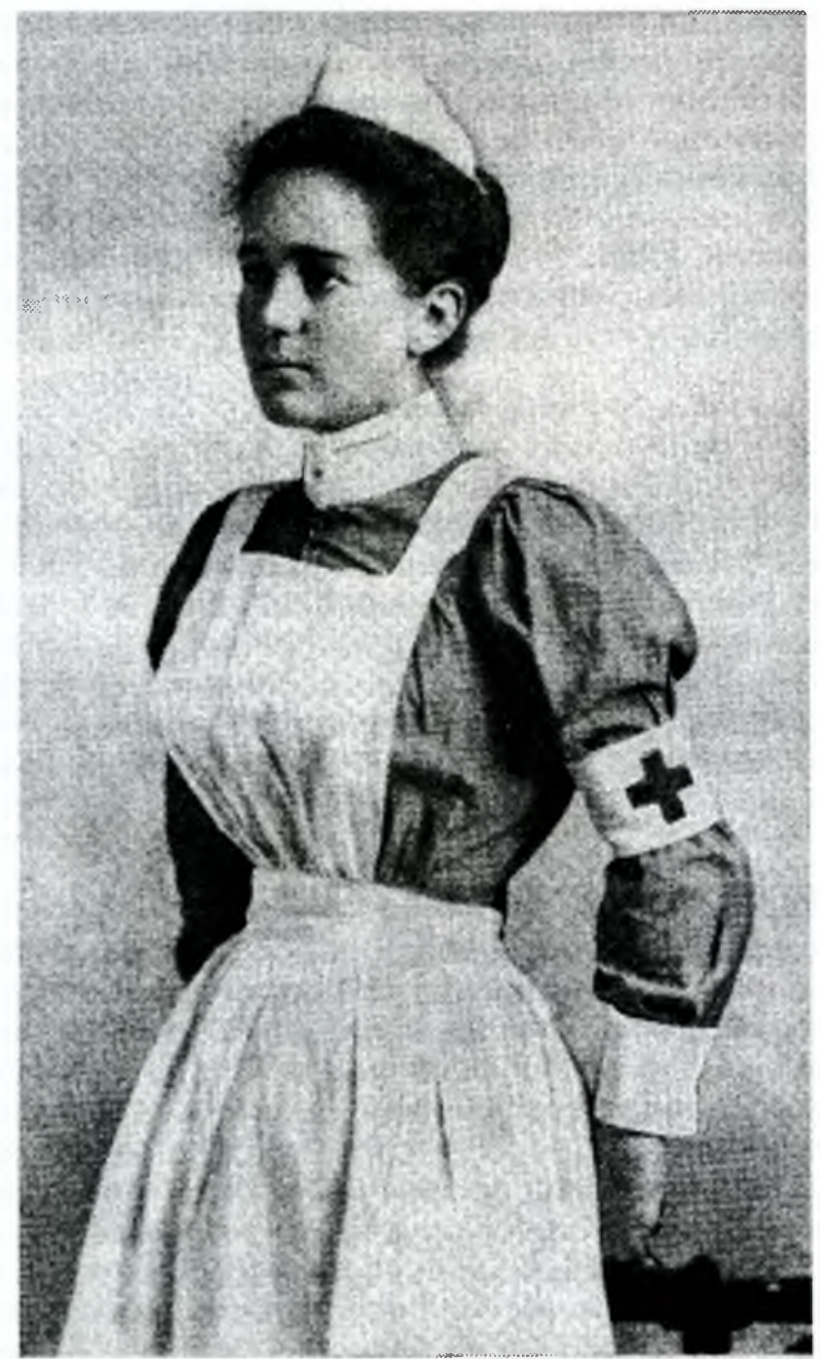

vredesonderhandelinge noukeurig gevolg. Sy het vas geglo dat die Boere, ten spyte van die Britse getalle-oorwig, nie as 'n verslane volk uit die stryd sou tree nie. Daarom was die vredesvoorwaardes vir haar 'n groot skok. 
Gedurende hierdie oorlog is, soos met alle oorloe die geval is, die dramatiese oomblikke afgewissel deur prosaiese eenselwigheid. Johanna het in haar dagboek die dramatiese insidente soos die anneksasie van Pretoria, die besoek van konsuls aan Irene en die spioene se besoeke, afgewissel met uiteensettings van haar belewing van die alledaagse gebeure en het sodoende lig gewerp op die doen en late van die inwoners van Pretoria: die militêre personeel, mediese personeel, kampbewoners, hensoppers en vrouens van vegtende burgers. Baie van die inskrywings is van 'n persoonlike aard soos haar verlange na haar verloofde, haar bekommernis oor haar moeder se gesondheid en haar broers se veiligheid op kommando. Andersyds bevat die dagboeke lang beskrywings van klimaatstoestande, musiekbyeenkomste of alledaagse huishoudelike aktiwiteite. Hierdie gedetaileerde inskrywings is van onskatbare waarde vir die studie van kultuurgeskiedenis.

Vanuit 'n historiografiese oogpunt beskou, vergelyk dié dagboek gunstig met soortgelyke geskrifte uit die oorlogstryd, soos dié wat deur Jan Celliers (Oberholster, 1978), Henriëtta Armstrong (Van Rensburg, 1980), tant Alie van Transvaal (Badenhorst, 1939), Slegtkamp van Spioenkop (Mostert, 1935) en Jack Hindon (Preller, 1942) opgeteken is. Wat veral voordelig is by die studie van Johanna se dagboek is die korrekte taalgebruik en spelling en die leesbaarheid daarvan, omdat dit ongeskonde bewaar gebly het. Johanna van Warmelo se oorlogsdagboek is 'n kosbare kleinnood wat in die Nederduitsch Hervormde Kerkargief in bewaring gehou word. Alhoewel verskeie navorsers al die oorblywende sewe volumes daarvan geraadpleeg het, is dit nog nie ten volle ontgin of gepubliseer nie.

\section{Johanna se keuse van skryftaal}

Die keuse van 'n skryftaal was vir Johanna in later jare 'n persoonlike dilemma. Sy kon ewe gemaklik in Nederlands, Afrikaans en Engels skryf. Omdat haar skoolopleiding deur medium van Engels was, was dit aanvanklik die taal waarin sy die meeste geskryf het. Die gebruik van Engels as skryftaal, en selfs in die daaglikse omgang, het by haar 'n gewoonte geword. Gedurende die oorlogsjare het dit tot Johanna se voordeel gestrek dat sy Engels goed magtig was, want alle korrespondensie moes ter wille van die sensor in Engels gewees het. Haar hele dagboek was gevolglik in Engels geskryf. Na die oorlog het haar patriotiese trots en haar huwelik met 'n Nederlander haar gedwonge laat voel om in Nederlands te skryf. Tog het sy nie vertroue in die skryf van Nederlands met die oog op 'n volwaardige publikasie gehad nie. Die uitgewer Stephen Black het aan haar geskryf dat "... going carefully into the book, I see that you write Dutch and English equally well ..." (Black, 1913; kyk NHKA 162/1). Dit was nadat hy die afdrukke van Johanna se Nederlandse briewe in die Engelse manuskrip bestudeer het. 
Johanna kan nie beskou word as 'n taalstryder van die Tweede Afrikaanse Taalbeweging nie, waarskynlik omdat sy besluit het dat Engels en Nederlands die aangewese tale vir haar boeke was. Tog het sy onbewus bygedra tot dié beweging. Die nasionale nood het van haar 'n volkskrywer gemaak. Haar publikasies staan direk in diens van die anti-Britse propaganda tydens en na die oorlog, maar dit was nooit direkte haataanvalle nie. Terwyl sy gepoog het om objektief te bly, het sy met tye emosioneel geraak.

Johanna se skryfstyl word gekenmerk deur eenvoud maar is nogtans boeiend. In enkele kort sinne kon sy daarin slaag om 'n hele beeld te skep - sy het geteken met die pen. Haar beste skryfwerk in dié trant was in Engels.

\section{Historiese agtergrond van Johanna van Warmelo se oorlogdagboek}

\subsection{Die eerste fase van dle oorlog}

Johanna en haar ma was in Pretoria woonagtig toe die Anglo-Boereoorlog op 11 Oktober 1899 uitgebreek het. Sy het op die vooraand van die stryd reeds aangevoel dat 'n grootse gebeurtenis aan die kom is. Dit word bevestig deurdat sy die dagboek waarin sy haar en haar ma se Europese toer twee jaar tevore beskryf het, weer uitgehaal en haar eie oorlogskronieke daarin begin aanteken het (Dagboek I:1; kyk NHKA). ${ }^{2}$ Aangesien sy reeds op 30 September 1899 haar eerste inskrywing gemaak het, het sy waarskynlik agterna die opskrif "Notes on the 'Franchise' War' bygevoeg, want op daardie stadium was die oorlog nog nie verklaar nie.

Aanvanklik was die aard van Johanna se dagboek blote verslaghouding van die verloop van die oorlog. Al die datums en inligting stem nie altyd ooreen met historiese feitlikhede nie, wat die vermoede versterk dat sy sommige inskrywings eers later gemaak het. Baie van haar inligting het op mondelinge oorvertelling berus. Sy het dikwels ook nie geweet watter van die verwarrende berigte die waarheid was nie. "Dear diary, I would write in you every day if we did not hear so many lying reports that we never know what to repeat and what not", skryf sy op 6 Augustus 1900 (Dagboek I:40). Die probleem is vererger deur die streng sensormaatreëls en die veranderde oorlogsomstandighede gedurende die guerilla-tydperk, want in Januarie 1901 skryf sy "... you must understand when I say 'we hear' or 'it is said' that I am only quoting rumours that reach us and that I cannot vouch for the truth ..." (Dagboek III:1). Die een dagboek het later tot sewe volumes gegroei - vol inligting oor die oorlog

2 Verwysings na NHKA LIX word voortaan in die teks slegs aangedui as Dagboek I, II, ens. 
Met die koms van die winter in die jaar 1900 was dit vir Johanna duidelik dat dit die Britte se oogmerk was om Pretoria te verower. Op 25 Mei I900 is die eerste gebulder van kanonne in Pretoria gehoor, terwyl Johanna dit self die eerste keer op 30 Mei gehoor het. Op 4 Junie het die Britse mag uit die suide die Hennopsrivier (Sesmylspruit) oorgesteek. Roberts het Swartkops (Zwartkops) teen eenuur die middag beset en enkele kanonskote op forte Klapperkop en Skanskop laat afvuur - aanvanklik onbewus daarvan dat die Boere reeds hulle kanonne verwyder het as versterking vir die burgers in die veld. Daarbenewens het die Britte ook gepoog om die spoorweglyn by Pretoria-stasie met swaar kanonne te ontwrig. Die bomme het meestal op die woongebied Sunnyside geval terwyl die stasie ongeskonde gebly het. Vir Johanna en haar ma was dit 'n skrikwekkende ervaring. Sy het dit so in haar dagboek beskryf: "The bombs began to burst in Sunnyside and we had to flee to Town for safety ... Harmony was directly in the line of fire ... we fled, leaving our dinner standing on the table. The shells went shrieking and whistling through the air over our heads ..." (Dagboek I:25).

\subsection{Die inname van Pretoria, Junie 1900}

Hierna volg die amptelike oorgawe van Pretoria, op 5 Junie 1900. Johanna het hierdie geleentheid, wat op Kerkplein voor die pas voltooide Raadsaal geskied het, bygewoon. Sy het daarvan seker gemaak dat almal geweet het waar haar simpatie gelê het, deur die Transvaalse vierkleurlint om haar hoed te bind. Alhoewel haar ma nie kans gesien het om saam te gaan nie, het Johanna gevoel dit was van historiese belang om die verrigtinge waar te neem want "... I think such things will become historical and everyone ought to see them [the troops]." Sy bly die hele tyd daar en verkyk haar aan die "... marching and parading and shouting and band playing ..." wat ongeveer twee-uur die middag begin het. Sy was geskok oor die blydskap wat daar geheers het onder mense wat sy as "redhot Republicans" beskou het (Dagboek I:26).

Nadat die Union Jack gehys is, volgens Johanna omtrent teen drie-uur die middag, het sy gevoel dat almal juig, maar “... only this poor child stood like a marble statue and soon afterwards she nearly fainted, what with heat, emotion and fatigue ... but I shall never regret having seen what I saw today". Aan die einde van dié dramatiese dag skryf sy: "Oh, dear diary, if ever we shall require courage and patriotism and loyalty it is now and now I shall stick to my colours. I think there is a bitter time before us ..." (Dagboek I:27-28).

Onmiddellik na die oorname van Pretoria het sommige Britse troepe in die omgewing van die Britse Residency in Rissikstraat kamp opgeslaan. Dit het spoedig vir Johanna duidelik geword dat Sunnyside'n gesogte blyplek vir hooggeplaasde Britse amptenare en militariste was. So het sy en haar ma letterlik binne permanente hoorafstand by die oorlog betrokke geraak. Dit was as gevolg van die ligging van Harmony. Die landgoed was geleè aan die westekant van Sunnyside langs die Apiesrivier, redelik naby aan die destydse Pretoria- 
stasie. Die Harmony-huis was geleë slegs $400 \mathrm{~m}$ vanaf die Britse Residency, die voor-oorlogse woning van die Britse verteenwoordiger in die $Z A R$, sir William Conyngham-Greene. Dit het op die noordwestelike hoek van Rissik- en Mearstrate gestaan. Na die Britse besetting is Harmony van alle kante deur vyandelike soldate omring. Aan die oostekant was die kamp van die berede militêre polisie; aan die westekant, langs Bereapark op die oewers van die Apiesrivier, was die persoonlike lyfwag van die Britse opperbevelvoerder, lord Roberts, wat vir 'n kort wyle in die Residency gevestig was. Na sy verhuising na die bekende Melrosehuis in Jacob Maréstraat, het die Residency die setel van die Britse militêre goeweneur, genl.-maj. J.G. Maxwell, geword.

Aan die suidekant van Harmony was die Montmorency-verkenners. Aan die noordekant het die hoof van die Britse militêre polisie 'n woonhuis op die hoek van Rissik- en Joubertstraat betrek. Reg voor Harmony het die Britse hoofkwartier-personeel die woonhuis van B.T. Bourke betrek. Vir Johanna was dit baie gerieflik want "... we can always see when there is some excitement going on". Na Johanna se oordeel was daar geen plek in Pretoria wat so deur waaksame Britte omring was as Harmony nie (Brandt, 1915:39-40).

\section{3 'n Jaar van frustrasie, Junie 1900-Junie 1901}

Johanna se dagboekinskrywings dui daarop dat die eerste jaar na die besetting van Pretoria vir haar 'n tydperk van intense frustrasie was. Sy was bewus van wat sy beskryf het as die hardvogtige optrede van die Britte deur hulle verwoesting van Boerewonings en die wegstuur van vrouens en kinders van vegtende burgers. Met verontwaardinging het sy in haar dagboek geskryf: "They are destroying farms, wholesale blowing up houses with dynamite, cutting trees down ... burning cornfields and everything else that they can lay hands on ..." (Dagboek I:45).

Ondertussen het sy en talle ander republikeinsgesinde Pretorianers uitgesien na 'n Boere-aanval op die besette stad. So teken sy aan:

An attack on the town was expected and every night the search-lights were used from the forts. We are even told that a week ago two trains were standing ready all night to remove Kitchener and his staff in case of danger. Trenches have been dug all round the Town, electric wires put up and every hill is bursting with cannon - in fact every imaginable precaution has been taken against the recapture of Pretoria (Dagboek II:10).

Johanna het vas geglo dat kommandant-generaal Louis Botha skielik een nag sou toeslaan, alle krygsgevangenes sou vrylaat en dan weer sou padgee, want volgens haar was daar te veel Britse artillerie om Pretoria in Boerehande te hou. Die moontlikheid van 'n Boere-aanval op Pretoria was egter skraal, want daar was te veel burgerlikes wat in 'n moontlike geveg beseer of gedood kon word. 
Tot Johanna se verdere frustrasie het talle van die jong burgers wat deur die Britte krygsgevange geneem is, geredeneer dat dit beter was om die eed van trou aan die Britse monarg af te lê as om Ceylon toe gestuur te word. Die kans op die ontsetting van Pretoria deur die Boeremagte was altyd 'n moontlikheid om in gedagte te hou, want dan sou hulle ten spyte van die eed onmiddellik beskikbaar wees om die stryd voort te sit. $\mathrm{Na}$ 'n jaar van vergeefse hoop het baie van die jong manne rusteloos begin raak. Die Britse owerhede het bowendien begin om van hulle weg te stuur want “... the English have found out that men are continually escaping - but they cannot find out how it is done. Pretoria is so well guarded that one would think it an utter impossibility for even a mouse to get out unseen" (Dagboek III:91). Ten spyte van die Britte se verskerpte waaksaamheid het H.W. Wilson (Wilson, 1901-1902:638) uit 'n Britse oogpunt geskryf: “... the traitors [patriotiese Boere] within Pretoria moved in and out of the town almost nightly ...".

\subsection{Johanna raak betrokke by spioenasie-aktiwiteite}

Dit is duidelik dat die Van Warmelo's nie in die eerste jaar van die besetting aktief by hulpverlening tot ontsnappingspogings betrokke was nie. Slegs twee weke voor Johanna as 'n vrywillige verpleegster by die konsentrasiekamp in Irene begin werk het, het mev. Van Warmelo egter besluit dat dit hulle plig was om hulp te verleen aan die jong burgers wat die stad wou verlaat om by die Boerekommando's te gaan aansluit. Hulle het vervolgens by mev. Celliers (die digter Jan F.E. Celliers se vrou) besonderhede oor die ontsnappingsmetodes ontvang. Johanna meld hieroor net die minimum in haar dagboeke:

... this is such a secret that I am quite afraid of putting it on black and white. Spies help the men out of Town - our own spies who come in when there is no moon and always take one or two men with them. They have to pass through untold dangers and suffer untold privations, but they do it and as far as we know, they have always reached the commandos in safety (Dagboek III:93).

Alhoewel Johanna ongetwyfeld begeester was deur haar landgenote se gevaarlike ondernemings, het sy versigtigheidshalwe in haar dagboek geen verdere vermelding gemaak van spioenasieaktiwiteite nie behalwe vir die een inskrywing “... Mama had a great deal to tell me but as they are secrets of the utmost importance - dangerous secrets - I shall not mention them here ..." (Dagboek IV:167). Dié geheime het sy meer as tien jaar later eers in Die Kappiekommando geopenbaar.

Omdat die Britte militêre sensorskap ingestel het, het die Van Warmelo's vindingryke planne gemaak om inligting na familielede en vriende te versend. Die besonderhede daaroor is nie hier ter sprake nie. Die Britse sensor moes mettertyd 'n vermoede gekry het dat die Van Warmelo's onwettig inligting 
bekom en het sy waaksaamheid verskerp sodat selfs die onskuldigste mededelings verlore geraak het. Indien hulle dan wel pos gekry het, was dit onherkenbaar vermink. Op 16 Julie 1901 teken Johanna in haar dagboek aan:

The letter ... was censored, as most letters are, and something it contained was evidently not to Mr Censor's taste, for he scribbled over it in thick ink and very impolitely wrote over it 'We are soldiers of the King and we'll fight for England's glory to the bitter end ...' (Dagboek VI:31).

Omdat die twee dames se slim planne om die sensor te ontduik, onder hul vriende bekend geraak het, is hulle deur Boerespioene wat van hul sukses verneem het, genader om hulle te help met die onwettige versending van inligting wat volgens die regulasies van die Britse militêre sensor ontoelaatbaar was. Dit het weer onwillekeurig daartoe gelei dat hulle by aktiewe anti-Britse aktiwiteite betrokke geraak het.

\subsection{Kontak met Boerespioene}

Willem Botha was die eerste Boerespioen wat 'n besoek aan mev. Van Warmelo gebring het met die doel om van haar dienste as spioen gebruik te maak. Hy het haar ingelig oor die bestaan van die Geheime Diens Kommissie wat verantwoordelik was vir die ontsnappingsnetwerk en haar medewerking gevra om behulpsaam te wees met die stuur van inligting aan president Paul Kruger in Europa.

Dit was destyds 'n gevaarlike onderneming om spioenasie-aktiwiteite te onderneem. Die Van Warmelo's het hulle aan vervolging deur die Britte blootgestel wat selfs tronkstraf kon behels. Die kanse dat hulle gevang kon word, was groot, want Pretoria het gewemel van Boere-verraaiers. Die Boere wat hulle deur die Britte laat omkoop het om die wapen teen hulle eie mense op te neem, het die naam "National Scouts" gekry, maar is deur hulle eie mense as verraaiers, "hensoppers", "joiners" of "hanskakies" beskou. Johanna het groot minagting vir die Scouts gehad en ag hulle as vir altyd verlore "... veracht door de Engelschen, die hem gebruikten voor hun eigen doel, gehaat door de Boeren; zijn goeden naam, zijn eer en zelfrespect kwijt" (Brandt-van Warmelo, 1905:9).

Johanna was om begryplike redes versigtig in haar verslaghouding in haar dagboek. Oor haar eie betrokkenheid by spioenasie het sy min neergeskryf. Dagboek V, wat handel oor die tydperk 28 Junie tot 12 Julie 1901, die laaste twee weke van haar verblyf in Irene, het verlore geraak. Dit sou waarskynlik die inligting van hoe sy al meer by die spioenasienetwerk betrokke geraak het, bevat het. Slegs enkele dae later het sy aktief met die "Geheime Dienst Kommissie" begin saamwerk toe haar paadjie en dié van kapt J.J. Naudé vir die eerste keer gekruis het. 
Dagboeke as corlogsdokumentasie ... Johanna van Warmelo

Voorbeeld van'n geheime brief

Pretoria $12726: x g_{2}$

van Hoofo inativ.

dan President.

mek de commando

gat alle. ngy joow

het jeff de als ben

Des hler was. Wy hedben

veel ammunctie gearomen in

de lachle ty g gen gebret aan

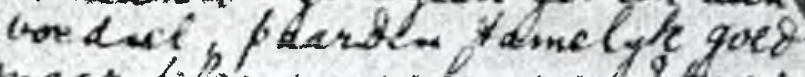

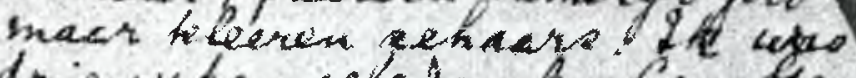
drie weken geleden by Com. Ten.

Rlla wel datex ogghing gejong

burgers wol envel. Yogdd betiekten oxtiangen van Pres. Stcyn - alles.

vif in Ory ltact, Nolonisten eluition hoy dajelyk: an. Gen. Bothe io

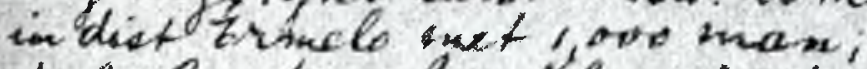
de la Rey twecchen Klertaparp 2.1 Ruotenturg, 1,500 san; Beyere hy

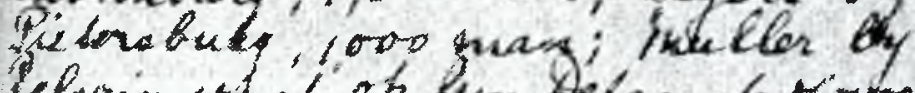

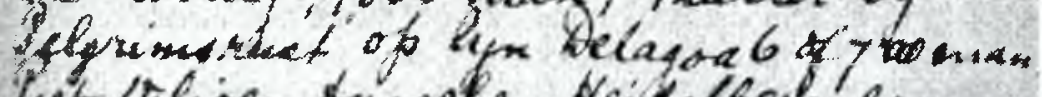
Pet vifion tweehen Acilelfor Ra

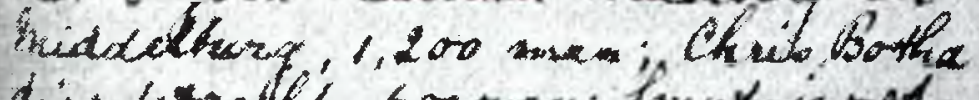

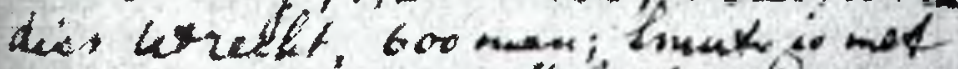
1500 in naser de talonic. Hese

78 ISSN 0258-2279 Literator 20(3) Nov. 1999:69-86


Naudé is in Junie 1901 deur genl. Louis Botha aangestel as hoof van die "speciale diensten". Dit het daarop neergekom dat hy in bevel was van 'n groep manne wat die kommando's van inligting moes voorsien. Hulle het van nievegtendes - manne en vroue - in Pretoria se hulp gebruik gemaak om hulle by te staan. Hierdie groep Pretoriase medewerkers van Naudé het die naam van "Geheime Diens Kommissie" aangeneem. Volgens Johanna was daar nie "... bekwamer, onverschrokkener of getrouwer mannen ... te vinden" nie (Brandt, 1915:150).

Op 17 Julie 1901 het Willem Botha die Van Warmelo's in kennis gestel dat Naudé en sy privaatsekretaris die vorige nag in Pretoria aangekom het. Hulle sou die volgende nag weer vertrek, maar Naudé het 'n boodskap gehad wat hy aan niemand anders as mev. Van Warmelo wou oordra nie. Die volgende dag het Johanna en Naudé vir die eerste keer ontmoet toe hy haar en haar ma ingelig het oor die onlangse konferensie wat die Boeregeneraals en hulle regerings te velde gehou het waar hulle gesamentlik besluit het om " $\ldots$ schouder aan schouder te staan tot de onafhanklikheid herwonnen zou zijn" (Brandt, 1915:170). 'n Afskrif van dié besluit was in Naudé se besit en mev. Van Warmelo moes dit na Holland laat smokkel sodat dit by president Kruger en spesiale gesant Leyds kon uitkom. Die Van Warmelo's was nou in die gevaarlikste bedrywighede van die oorlog gedompel: waar dit met die onskuldige deursmokkel van oorlogsnuus begin het, het hulle nou volwaardige spioene geword - 'n nog gevaarliker stap. Skuldigbevinding aan spioenasie in oorlogstyd was immers met die dood strafbaar.

Naudé het na sy eerste kennismaking met die Van Warmelo-dames besef dat vrouens baie goeie speurders kon wees. Johanna was volgens hom by uitstek geskik vir spioenasiewerk omdat sy Engels vlot kon praat en tydens haar verblyf in die konsentrasiekamp het sy in direkte verbinding met die leërowerhede gekom. So kon sy inligting bekom uit bronne wat vir ander geslote was.

Vanaf Julie tot September 1901 was Johanna op verskillende maniere besig om die spioene van inligting te voorsien en om hulle behulpsaam te wees waar moontlik. Een van haar moeilikste opdragte was om 'n spoorwegtydtafel vir die spioene in die hande te kry. Dié dokument het alle besonderhede bevat oor die bewegings van Britse militêre treine. Johanna het die gevaar verbonde aan die verkryging daarvan besef en skryf tereg: "That timetable alone is enough to bring us to the stake ..." Aan die een kant was sy, nadat sy die tydtafel veilig in Naudé se hande besorg het, verheug oor die sukses wat die Boere behaal het met behulp van die inligting wat dit bevat het.

It [the timetable] is working wonders judging by the number of trains that are flying into the air now. Last week three - all heavily laden with provisions. One had a lot of khakis on board and the poor things were awfully mauled about. I don't know how many were killed or wounded ... 
Aan die ander kant het haar gewete haar gepla. "The great loss of life in connection with these trains preys on my heart since we had a hand in it. I feel as if we are helping to murder and yet our commandoes are depending on the taking of those trains" (Dagboek VIII:6). Verder het sy ook 'n aandeel gehad in die versending van die dinamiet en lont wat gebruik is om die treine op te blaas. Hierdie dade was sekerlik die gevaarlikste van al Johanna se spioenasieaktiwiteite.

\subsection{Die spioenasienetwerk disintegreer en 'n nuwe komitee kom tot stand}

Teen die einde van Augustus 1901 het vier spioene wat nie aan Naudé se netwerk behoort het nie, by die Van Warmelo's kom skuiling soek: ene Kuypers en nog drie ander. Mev. Van Warmelo het geweier om hulle in haar huis toe te laat. Johanna het haar gesmeek "... to take pity on these men but (most fortunately) she would not hear of it. The men were concealed by other friends

We had nearly forgotten them when news reached us of their capture last week ..." (Dagboek VIII 4).

Met 'n groot skok het hulle verneem dat Kuypers, ten einde nie voor 'n vuurpeleton te sterf nie, glo een van die kroongetuies geword het wat al die spioene verraai het en ook die name onthul het van persone wat huisvesting aan spioene in Pretoria gebied het. Die Van Warmelo's het die volgende paar dae in angs die verwikkelinge dopgehou want "... no one knows all the names of the people who have been betrayed. Ours may be one of them!" (Dagboek VIII:7). Met skok het hulle op 3 September verneem dat Willem Botha ook verraai en in hegtenis geneem is. Johanna het gevoel "... the cordon is drawing in around us and I feel tonight as if there is no way of escape for us ..." (Dagboek VIII:16). Die Van Warmelo's is egter nie verraai nie, want hulle het ongehindered in Harmony bly woon.

Naudé het ook mettertyd gehoor van die verraad, dat sy vernaamste spioene gevange geneem is en sy skuilplekke in Pretoria verraai is. Hy het besef dat die enigste huis wat nie onder verdenking gestaan het nie, Harmony, die tuiste van die Van Warmelo's, was. Ter wille van almal se veiligheid het hy egter besluit om hom voorlopig nie naby Pretoria te waag nie.

Aangesien die meeste van Naudé se kontakpersone in Pretoria verraai is, het Johanna besluit om 'n nuwe Geheime Diens Komitee saam te stel wat net uit 'n aantal dames bestaan het. Hul pligte sou wees om betroubare inligting te versamel wat hoofsaaklik uit Europese en Kaapse koerante verkry is, om veilige skuilplekke vir die spioene te kry en om offisielle verslae tussen die generaals aan die een kant en pres. Kruger en Leyds in Europa aan die ander kant te versend. Ook sou hulle poog om noodsaaklikhede (soos klerasie) aan die spioene te voorsien. Daar was egter niemand wat Naudé in kennis kon stel van 


\section{Kapt. J.J. Naudé}

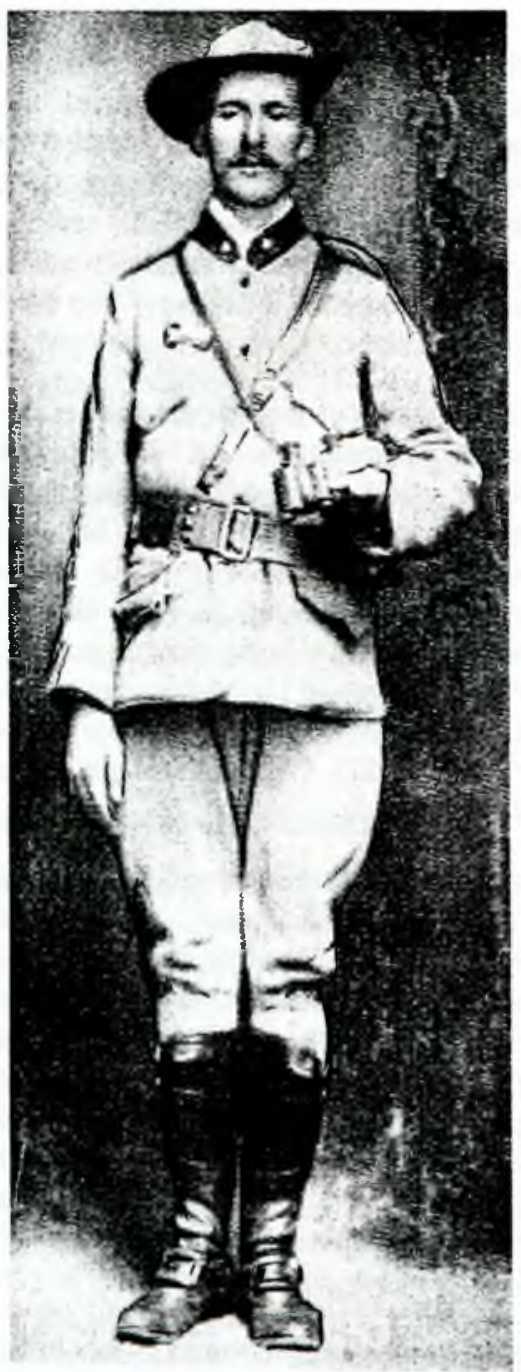


die nuwe komitee nie, want die meeste van die eertydse spioene wat by Naudé se netwerk betrokke was, is deur die Britte na konsentrasiekampe in Ceylon of Bermuda gestuur. Vir meer as twee maande het die komitee geen kontak met Naudé gehad nie. Dit het Johanna hartseer gestem, want haar kommunikasie met Leyds was op daardie stadium so doeltreffend dat sy na willekeur boodskappe by hom kon kry.

Aangesien die moontlikheid om Pretoria ongesiens binne te kom, al moeiliker geword het, het Naudé eers in Desember 1901 weer die stad besoek. Hy en sy kamerade het Harmony na donker die aand van 14 Desember bereik, en twee van hulle het daar oornag. Dit was die eerste keer dat die Van Warmelo's aan spioene skuiling gebied het. Naudé het op daardie stadium 'n losprys van $£ 2000$ op sy kop gehad en hy het die Van Warmelo's gewaarsku dat dit vir hulle lewensgevaarlik kon wees om hom te huisves. Tog het hulle nie gehuiwer om hom en sy maat te versteek nie.

Sowel die nuwe komitee as ander kontakpersone het op 15 Desember deur die loop van die volgende dag Harmony besoek. Johanna het as Naudé se sekretaris opgetree en het briewe aan Leyds gedikteer waarna die komitee die spioen gehelp het om die voorrade wat hulle gevra het, te verpak. Naudé en sy kamerade het Harmony na drie dae weer in hul kakie-uniforms verlaat. Ten spyte van al die voorsorgmaatreëls wat die Van Warmelo's getref het, moes die Britte onraad gemerk het want toe hulle die volgende oggend opstaan, gewaar hulle dat "overal stonden khakies in kleine groepies praten - hier officieren, daar speurders te voet en te paard - allen keken naar onze kant uit ..." (Naude, 1904:46; Brandt, 1915:346-355). Gelukkig het dit net by kyk gebly en is die Van Warmelo's met rus gelaat.

Intussen het Johanna verlof gekry om 'n vriendin in Johannesburg te besoek - sy wou wegkom van die spanningvolle situasie. In haar afwesigheid is Harmony op Sondagoggend, 19 Januarie 1902, deur die militêre polisie deursoek. Dit was vir mev. Van Warmelo duidelik dat hulle nie na dokumente of wapens gesoek het nie - daarvoor was die deursoeking te oppervlakkig. Nee, hulle het na spioene gesoek. Johanna skryf vol verontwaardiging in haar dagboek: “. .. it is a mystery to me how the English got such ideas of us in their heads. We are actually suspected of having harboured spies! What a lark! I can't help laughing at the idea of my proper old mother being in such a predicament, and that while 1 was away from home!" (Dagboek VII:157). Die Van Warmelo's het die huisdeursoeking gelate aanvaar

Na die huisdeursoeking is die Van Warmelo's deur hulle vriende aangeraai om die land te verlaat soos talle van die vrouens reeds gedoen het. Hulle het wel al hulle geld uit die bank getrek vir ingeval hulle gedwing sou word om te vertrek, maar het geweier om self die stap te neem, want Naudé sou hulle weer een of ander tyd kom besoek, wat wel gebeur het. Gedurende die nag van 9 Februarie 
maak Naudé en nog drie spioene hulle opwagting by die Van Warmelo's. Nadat die spioene daar oornag het, is hulle die volgende nag weer weg, toegerus met klerasie sowel as alle moontlike inligting wat die komitee intussen versamel het. Dit was Naudé se laaste oorlogstydse besoek aan Pretoria.

Naudé sluit sy memoirs In Doodsgevaar af met die gedagte dat hy dit as sy plig beskou om hulde te bring en 'n woord van dank en waardering te rig aan "... die trouwe Afrikaanse moeders en zusters, die schrijver dezes gedurende die moeilike dagen persoonlik hebben bijgestaan en in Pretoria op allerlei wyse geholpen hebben ter bevordering van onze taak daar buiten in het veld" (Naude, 1904:41). Met sulke vrouens, sê hy, kan 'n volk die toekoms hoopvol en opgewek tegemoet gaan. En wat Johanna self betref: dit was vir haar deurentyd opwindend om met spioene kontak te maak want "... it is most interesting and relieves the dreariness of our lives. [It is] ... refreshing ... to meet men who come straight from our commandos ... We know that these spies at least bring in reliable information" (Dagboek VIII:3).

Teen die einde van Februarie 1902 was Johanna van mening dat die oorlog nog 'n jaar of twee sou aanhou. Omdat daar nie meer spioenasie-aktiwiteite in Pretoria plaasgevind het nie, het sy gevoel dat sy niks meer kon doen om die Boere te help nie. Daarom het sy begin voorbereidings tref om na Europa te gaan waar haar toekomstige eggenoot, Louis Brandt, op haar gewag het. Sy het op 2 Junie 1902 in Kaapstad 'n skip gehaal, sonder dat sy besef dat die vredesluiting op 31 Mei 1902 plaasgevind het. Sy het eers op 14 Junie, tydens die vaart na Europa, met teleurstelling daarvan verneem.

\subsection{Johanna se rol in die spioenasie-aktiwiteite}

Johanna, 'n hoogsintelligente jong dame in haar vroeê twintigerjare, was amper twee jaar lank vasgekeer in 'n oorloggeteisterde Pretoria, omring deur Britse soldate met slegs haar ma as geselskap in die huis. By die bestudering van haar dagboek is dit duidelik waarneembaar dat sy nie tevrede was om net die rol van 'n Victoriaanse jongmeisie te vertolk nie: alhoewel sy 'n besige sosiale lewe gelei het, was dit nie vir haar genoeg nie - daarvoor was sy fisies en geestelik te aktief. Ook het haar dagboek, wat aanvanklik as 'n vorm van oorlogsverslaggewing begin het, daartoe gelei dat sy besonder belang begin stel het in alle oorlogsnuus. In die ses gewone volumes wat behoue gebly het, word byna by elke inskrywing melding gemaak van die bewegings van die burgers of Britse troepe, van veldslae en van ongevalle. Na die val van Pretoria het oorlogsnuus skaarser geword en het die klem begin val op die bewegings van burgers wat hulle lewens gewaag het om weer by die Boerekommando's uit te kom om 'n laaste poging aan te wend om vir volk en vaderland te veg.

Johanna het een van haar dagboeke benut om gevaarlike en vertroulike inligting te boekstaaf deur met suurlemoensap daarin te skryf. Dit was dan onsigbaar 
maar sodra dit aan hitte blootgestel word, kom die skrif na vore. Sy het die boek onder andere tydens die huisdeursoeking ewe blatant op 'n kas laat lê. Dié boek het bewaar gebly en die skrif het mettertyd sigbaar geword.

Ten spyte van al die beperkende maatreëls het Johanna-hulle tog daarin geslaag om byna ' $n$ jaar lank inligting na die buiteland te stuur. Talle van die boodskappe het Kruger en Leyds via Johanna se verloofde in Nederland, Louis Brandt, bereik. Die metode wat hulle aangewend het, was om soos in die vertroulike dagboek met suurlemoensap in plaas van ink te skryf. Johanna se boodskappe aan Leyds kan as die hoogtepunt van haar spioenasiekorrespondensie beskou word. Die dokumente wat hy van Johanna ontvang het, het sorgvuldig bewaar gebly. Die eerste kontak was sy met hom gemaak het, was 'n brief gedateer 22 Oktober 1901 (Leydsargief, dok. 97, kyk NA).

\section{Waar kom Die Kappiekommando vandaan?}

Johanna het kort na haar huwelik in Nederland met Louis Brandt in Augustus 1902 aan haar eerste boek, Het Concentratie-kamp van Irene, begin skryf. Dit is in 1905 gepubliseer. Dié boek het berus op haar dagboekinginskrywings tydens haar verblyf in daardie konsentrasiekamp as vrywillige verpleegster.

Die idee om ook 'n boek oor haar spioenasie-aktiwiteite te skryf, het reeds in 1902 by Johanna ontstaan. Sy het egter eers in 1911 daartoe oorgegaan. Haar idee was om iets te skryf wat populêr sal wees, maar nogtans boeiend en interessant sodat sy die "geschiedenis van deze kritieke jaren ..." kon bekend maak (Brandt, 1915:xiv).

Omdat sy vlot kon Engels praat en skryf, het sy die boek in Engels geskryf onder die titel The Petticoat Commando. Sy het op daardie titel besluit omdat dit sou "... aantoont dat dit over het vrouw in oorlogstyd is, en alle namen was even banaal en afgesaagd ... Deze titel zal aandacht trekken en klinkt niet te oorlogachtig" (Johanna, 1911; kyk NHKA). Sy het die Engelse manuskrip aan lord Selborne gestuur om sy opinie oor die inhoud daarvan sowel as sy hulp met die publikasie te vra. Ook sir Patrick Duncan het 'n bydrae gelewer deur die voorwoord tot die Engelse weergawe te skryf. Sowel Selborne as Duncan was bekende Britse amptenare in Suid-Afrika.

Wat die titel van die Nederlandse uitgawe betref, het Johanna aanvanklik besluit op "Het vrouwen kommando", maar sy was nooit tevrede hiermee nie. Toe sy die probleem terloops aan Selborne vermeld het, het hy nadat hy die manuskrip van die Engelse weergawe gelees het, teenoor haar opgemerk: "But is "Het vrouwen kommando' the right Dutch title. Why not het 'Kappie Kommando'

.." (Selborne, 1912; kyk NHKA). So is die titel van hierdie patriotiese Afrikaanse verhaal ironies genoeg deur 'n Britse edelman geskep. Die titel het 
nie net trefkrag gehad nie, maar het inderdaad daartoe gelei dat die Afrikaanse taal 'n nuwe begrip bygekry het.

Die eerste uitgawes van Die Kappiekommando het in 1913 in sowel Nederlands as Engels verskyn. In 1958, 45 jaar later, het Johanna op 82-jarige ouderdom die Afrikaanse uitgawe voorberei. Sy wou self die vertaalwerk doen omdat sy gevoel het dat die tyd reg was vir 'n Afrikaanse vertaling. Waarom nie vroeër al 'n Afrikaanse uitgawe nie? Want “... sestig jaar gelede was ons volk nog sonder 'n eie taal"' (Brandt, 1958:xii). Dit is belangrik om hier te beklemtoon dat die kappiekommando van Johanna se Die Kappiekommando in der waarheid net uit 'n paar vrouens bestaan het, wat nooit fisies op kommando gegaan het nie, maar agter die skerms vir volk en vaderland geveg het.

Die befaamde letterkundige P.J. Nienaber is van mening dat Johanna "... met gloed en ywerige liefde [dit] wat gedoen is deur Boerevrouens om hul vegtende mans in die veld te hou en te ondersteun ..." beskryf het (Nienaber, 1938:105). Die Kappiekommando het aan al die kenmerke van die historiese romankuns van die begin van die twintigste eeu voldoen: dit was nog nie ver genoeg verwyder van die volksverlede om dit 'n ware kunswerk te maak nie; verder was daar oorvloedige beskrywings, 'n massa feite en 'n gebrek aan evokatiewe beskrywing.

Die Kappiekommando kan ook as 'n avontuurroman geklassifiseer word, waarin Johanna, haar ma en Naudé die heldefigure gevorm het met die historiese gebeure wat die raamwerk was vir die ervarings van die karakters. Die klem het op die heldedade van die dapper Boere geval. Die leser deel in die vreugde en smart van die oorlogsgebeure. G.D. Scholtz het Die Kappiekommando soos volg belewe:

Ek was 'n knapie van nog nie eers twaalf jaar oud nie toe my vader vir ons kinders Die Kappiekommando ... gekoop het. Só interessant het ek die boek gevind dat ek dit sommer driemaal agtermekaar deurgelees het. Iedere keer het ek meer en meer aangetrokke gevoel tot die figuur van die onversaagde Kapt. Naudé ... (Scholtz, 1940:ongenommer).

\section{Slot}

Albei Johanna se oorlogspublikasies (Iréne en Die Kappiekommando) was outobiografies van aard. Die heldin (in albei gevalle Johanna) kom na vore as die draer van die idee van dié tyd: vir volk en vaderland. Waar die historiese bewussyn van die volk aan die begin van die eeu nog nie in patriotiese krag en nasionale sterkte ontwikkel het nie, het Johanna se bydrae deur die skryf van Die Kappiekommando help bou aan die geestelike vorming van 'n nasionale bewussyn. Terselfdertyd was haar uitbeelding van haarself as 'n onverskrokke vegter allermins verwaand. Onbeperkte selfvertroue was eie aan haar 
geaardheid. In haar latere loopbaan het haar sterk, individuele en vreeslose optrede, onder meer ter wille van vroueregte, telkens haar tydgenote beïndruk.

\section{Literatuurlys}

Badenhorst, A. 1939. Tant Alie van Transvaal. Kaapstad : Nasionale Pers.

Black

$k y k$ NHKA LIX

Brandt, J. 1915. Die Kappie Kommando of Boerevrouwen in Geheime Dienst. Amsterdam, Pretoria : De Bussy.

Brandt, J. 1958. Die Kappiekommando of Boervroue in geheime diens. Kaapstad, Pretoria HAUM.

Brandt-Van Warmelo, J. 1905. Het Concentratie-kamp van Irene. Kaapstad : HAUM.

Dagboek $k y k$ NHKA LIX

Johanna $k y k$ NHKSA LIX

Leydsargief, dok. 97 $k y k$ NA

Mostert, D 1935. Slegtkamp van Spioenkop. Oorlogsherinneringe van kapt. Slegtkamp. Kaapstad : Nasionale Pers.

Naudé, J J 1904. In doodsgevaar. Pretoria : Volkstem-drukkerij.

Nienaber, P J. 1938. Die Afrikaanse roman-temalogie Amsterdam : Swets \& Zeitlinger.

Oberholster, A.G red. 1978. Oorlogsdagboek van Jan F.E. Cilliers, 1899-1902. Pretoria RGN.

Preller, G.S. 1942. Kaptein Hindon, oorlogsavonture van 'n baasverkenner. 3de druk Kaapstad : Nasionale Pers.

Scholtz, G D. 1940 In doodsgevaar. Die oorlogservarings van kapt J.J. Naudé. Johannesburg : Voortrekkerpers

Selborne $k y k$ NHKA LIX

Van der Merwe, M.E. 1989. Johanna Brandt en die kritieke jare in Transvaal, 1899-1908 Pretoria : UP. (M.A.-verhandeling.)

Van Rensburg, T. red 1980. Camp diary of Henrietta E.C. Armstrong. Experiences of a Boer nurse in the Irene Concentration Camp, 6 April-11 October 1901. Pretoria : HSRC.

Wilson, H W. 1901-1902. With the flag to Pretoria. A history of the Boer War of 1899-1902. Volumes I - II. London : Harmsworth \& Amalgamated Press.

\section{Argivale bronne}

\section{NHKA LIX}

kyk Nederduitsch Hervormde Kerkargief, Pretoria; L.E Brandt-versameling

Nederduitsch Hervormde Kerkargief, Pretoria; L.E. Brandt-versameling

- Dagboek: Oorlogsdagboeke van Johanna Brand-Van Warmelo

- Black (1913): Brief van Black aan Johanna (17 Aug. 1913)

- Johanna (1911): Brief van Johanna aan haar skoonfamilie (29 Nov. 1911)

NA

- Selbome (1912): Brief van Selborne aan Johanna (18 Mei 1912)

kyk Nasionale Argief, Pretoria; Leydsargief

Nasionale Argief, Pretoria; Leydsargief

- Leydsargief dok. 97: Vierde verzameling geheime korrespondensie, vol 94:1899. 1902, deel 1, dokument 97 